\title{
THE PRODUCTION OF ANTI-HUMAN GLOBULIN SERUM (COOMBS REAGENT) IN GOATS
}

\author{
BY \\ I. DUNSFORD AND C. C. BOWLEY \\ From the National Blood Transfusion Service, Northfield Road, Crookes, Sheffield
}

(RECEIVED FOR PUBLICATION MARCH 8, 1956)

The rabbit is customarily used for the preparation of anti-human globulin serum, but there are several objections to the choice of this animal. These are: (1) The volume of serum obtained is small. To maintain supplies it is necessary either to have several animals producing the reagent, or to hyperimmunize and bleed the rabbits used too frequently, which in turn results in a less specific reagent. (2) The rabbit is prone to myxomatosis.

This note reports the preparation of the reagent in the goat. The procedure has the following advantages over preparation in rabbits: (1) It yields larger volumes of serum. (2) The goat is not prone to infection with myxomatosis. (3) The immunizing and bleeding operations are simpler and quicker. (4) For the laboratory using or distributing large quantities of the reagent feeding and housing a goat is less costly than keeping $\mathbf{2 0}$ or 30 rabbits.

\section{Method}

Sterile group $O$ serum, $5 \mathrm{ml}$,, was injected intramuscularly (gluteal muscles) every three to four days to a total of 10 injections.

Ten days after the last injection $10-20 \mathrm{ml}$. blood was withdrawn from the leg vein.

After heating the serum at $56^{\circ} \mathrm{C}$. for 30 minutes (to inactivate complement) the serum was titrated in parallel against red cells sensitized with an incomplete anti-D and against unsensitized cells.

Provided that the titre against the sensitized cells was at least 20 times as great as that against the non-sensitized cells, the goat was bled from the external jugular vein for 400 to $500 \mathrm{ml}$. The hair of the neck was closely clipped and a long $(20 \mathrm{~cm}$.) largebore needle $(3 \mathrm{~mm}$. external diameter) used. The blood was allowed to run straight from the needle into a sterile bottle.

After clotting the serum was separated with aseptic precautions. Following inactivation of the complement as before, the anti-human agglutinins were removed by absorption with well-washed $\mathrm{A}, \mathrm{B}$, and $\mathrm{O}$ cells as for rabbit anti-human globulin serum.

The goat anti-human globulin serum was standardized in the same manner as rabbit anti-human globulin serum. (A detailed description of these absorption and standardization techniques has been published elsewhere (Dunsford and Bowley, 1955).)

\section{Results}

Titre Values.-The anti-human globulin serum produced after the first course of injections had a titre of 1 in 64 . After six months' rest a further three injections of $5 \mathrm{ml}$. sterile group $O$ serum raised the titre to 1 in 1,000 , and after a further rest period the titre was boosted to 1 in 4,000 , at which level it has subsequently remained. Of interest is the low titre of anti-human species specific agglutinins. This has remained at 1 in 2 to 1 in 4 throughout. The serum still shows very little prozone and at no dilution has it given negative results. A second goat similarly immunized has given an equally satisfactory reagent.

Routine Laboratory Use.-The goat antihuman globulin serum was used at its optimum dilution in parallel with rabbit anti-human globulin serum prepared by the alginate (Slavin, 1950) method, also at its optimum dilution, for both direct and indirect Coombs tests.

$\begin{array}{lcccr}\text { Total number of tests in parallel } & \ldots & 2,609 \\ \text { Both results negative } & \ldots & \ldots & \ldots & 2,506 \\ \text { Discrepant results } & \ldots & \ldots & \ldots & 93 \\ \text { positive } & . & . & \ldots & 10\end{array}$

All the discrepant results occurred in the direct Coombs test and the details are as follows:

\begin{tabular}{|c|c|c|c|}
\hline Case No. & $\begin{array}{l}\text { Coating } \\
\text { Antibody }\end{array}$ & $\begin{array}{c}\text { Rabbit } \\
\text { Anti-human } \\
\text { Globulin }\end{array}$ & $\begin{array}{c}\text { Goat } \\
\text { Anti-human } \\
\text { Globulin }\end{array}$ \\
\hline $\begin{array}{r}272328 \\
282871 \\
23115 \\
284220 \\
292316 \\
124746 \\
99527 \\
278033 \\
182863 \\
219673\end{array}$ & $\begin{array}{l}\text { Anti-D } \\
\text { Cold incomplete } \\
\text { Anti-D } \\
\text { Cold incomplete } \\
\text { Anti-D } \\
\text { Cold incomplete } \\
\text { Anti-D } \\
\quad, \text {, }\end{array}$ & $\begin{array}{l}-? \\
\overline{-} \\
\overline{-} \\
\bar{w} \\
\overline{-} \\
+\end{array}$ & $\begin{array}{l}(+) \\
w \\
(+) \\
+ \\
+ \\
- \\
(+) \\
w \\
++ \\
-\end{array}$ \\
\hline
\end{tabular}


Immuno-haematology.-Direct Coombs tests, quantities. Ample supplies of this essential using goat and rabbit reagents in parallel in serial dilutions, were carried out on the red cells from 11 cases suspected of suffering from acquired haemolytic anaemia, with the following results:

Total number tested

Negative reaction with goat and rabbit reagents

Positive results with goat and rabbit reagents

Discrepant results reagent could be made available throughout the country by adopting this procedure at a few suitable centres.

This method was suggested to one of us (I. D.) by Dr. Sol. Haberman. of Dallas, Texas, to whom grateful acknowledgments are made.

\section{Summary}

REFERENCES

The goat is a very satisfactory animal for preparing potent anti-human globulin serum in large

Dunsford, I., and Bowley, C. C. (1955). Techniques in Biood Grouping. Oliver \& Boyd, Edinburgh.

Slavin, D. (1950). Nature (Lond.), 165, 115. 